\title{
Static Analysis of Masonry Infilled R.C.Frame With \&Without Opening Including Soft Storey of Symmetric Building
}

\author{
Nikhil S. Agrawal ${ }^{1,}$ Prof. P. B Kulkarni ${ }^{2}$ \\ P.G. Student ${ }^{1}$, Civil Engineering Department, Shri.Ramdeobaba College of Engineering and Management, \\ Nagpur-440012, Maharashtra, India ${ }^{1}$ \\ Associate Professor ${ }^{2}$, Civil Engineering Department, Shri.Ramdeobaba College of Engineering and \\ Management Nagpur-440012, Maharashtra, India ${ }^{2}$
}

\begin{abstract}
Masonry infill is considered as a non-structural element in all type of buildings where masonry use. But, masonry infill walls are mainly used to increase initial stiffness and strength of reinforced concrete (RC) frame buildings. This Open First storey is also termed as "Soft Storey". The upper storeys have brick infilled wall panels with various opening percentage in it. In many cities of India, it is very common to leave the first storey of masonry infilled reinforcement concrete (RC) frame building open preliminary to generate parking space or any other usage in the first storey. Such buildings are highly undesirable in seismically active areas. In the present study, it is an attempt to access the performance of masonry infilled reinforced concrete (RC) frames with soft storey of with and without opening. In this paper, symmetrical frame of college building $(G+5)$ located in seismic zone-III is considered by modelling of initial frame. According to FEMA-273, \& ATC-40 which contain the provisions of calculation of stiffness of infilled frames by modelling infill as "Equivalent Diagonal Strut Method". Therefore, the infill panels are modelled as equivalent diagonal strut method. The error involved in modelling such buildings as neglecting the presence of infills in the upper storeys, is brought out through the study of an example building with different analytical models. This linear static analysis is to be carried out on the models such as Strut frame with 15\%, 20\%, \& 25\% centre \&corner opening, which is performed by using computer software STAAD-Pro from which different parameters are computed. In which it shows that how infill panels increase the stiffness of the structure. While the increase in the opening percentage leads to a decrease on the lateral stiffness of infilled frame. This paper highlights the importance of the presence of the open first storey in the analysis of the building.
\end{abstract}

Keywords: Masonry infilled frame, Stiffness, Equivalent Diagonal Strut Method, Seismic Effect, Opening percentage.

\section{Introduction}

Many urban multistorey buildings in India today have open first storey as an unavoidable feature. This leave the open first storey of masonry infilled reinforced concrete frame building primarily to generate parking or reception lobbies in the first storey. It has been known for long time that masonry infill walls affect the strength \& stiffness of infilled frame structures. There are plenty of researches done so far for infilled frames, however partially infill frames are still the topic of interest. Though it has been understood that the infill's play significant role in enhancing the lateral stiffness of complete structures.Infills have been generally considered as non-structural elements \& their influence was neglected during the modeling phase of the structure. A soft storey building is a multi-storey building with one or more floors which are "soft" due to structural design. These floors can be especially dangerous in earthquakes. As a result, the soft storey may fail, causing what is known as a soft storey collapse. Soft storey buildings are characterized by having a storey which has a lot of open space. Parking garages, for example, are often soft stories, as are large retail spaces or floors with a lot of windows. While the unobstructed space of the soft storey might be aesthetically or commercially desirable, it also means that there are less opportunities to install shear walls, specialized walls which are designed to distribute lateral forces. If a building has a floor which is $70 \%$ less stiff than the floor above it, it is considered a soft storey building. This soft storey creates a major weak point in an earthquake, and since soft stories are classically associated with reception lobbies retail spaces and parking garages, they are often on the lower stories of a building, which means that when they collapse, they can take the whole building down with them, causing serious structural damage which may render the structure totally unusable. As per Indian standard 1893 (part -I) 2002 code (BIS-2002) some design criteria are to be adopted after carrying out the earthquake analysis ,in which the columns and beams of the soft stories are the designed for 2.5 times the storey shears and moments calculated under seismic loads. 


\section{Analytical Methods}

Static or dynamic analysis can be classified into three broad categories, namely elastic analysis, plastic analysis and nonlinear analysis. Elastic analysis refers to the analysis where a linear elastic behaviour is assumed for the frame and the infill, and geometric and material nonlinearities are not included. In the case of a plastic analysis, an elastic-plastic stress-strain relationship is assumed for the materials, and the failure load of the in filled frame corresponding to collapse stage is determined. In the nonlinear analysis, the different sources of nonlinearity are included, and the response of the structure is traced in the entire loading range, from precracking to collapse. For most applications, codes of practice recommend an elastic analysis, because of the inherent complexity of a nonlinear analysis. The different models available for the elastic analysis of infilled frames can be classified into four groups based on their complexity. They are the stress function method, the equivalent diagonal strut method, the equivalent frame method and the finite element method.

\section{Equivalent Diagonal Strut Methods}

The simplest equivalent strut model includes a single pin-jointed strut. Holmes who replaced the infill by an equivalent pin-jointed diagonal strut made of the same material and having the same thickness as the infill panel suggest a width defined by,

$$
\frac{w}{d}=\frac{1}{3}
$$

Paulay and Priestley [32] suggested the width of equivalent strut as,

$$
w=0.25 d
$$

Where,

$\mathrm{d}=$ Diagonal length of infill panel

$\mathrm{w}=$ Depth of diagonal strut

However, researchers later found that this model overestimates the actual stiffness of infilled frames and give upper bound values. Another model for masonry infill panels was proposed by Mainstone in 1971 where the cross sectional area of strut was calculated by considering the sectional properties of the adjoining columns. The details of model are as shown in Fig. 4.2. The strut area $A_{s}$ was given by the following equation.

$\mathrm{A}_{\mathrm{e}}=\mathrm{W} \mathrm{t}$

$\mathrm{W}=0.175(\kappa \mathrm{H})^{-0.4} \mathrm{D}$

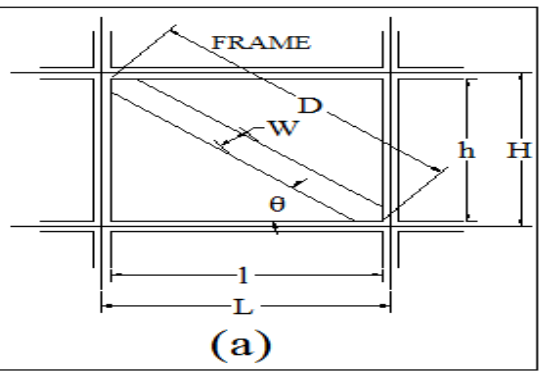

Fig. 1 Brick Infill Panel As Equivalent Diagonal Strut

$$
K=\sqrt[4]{\frac{E_{\mathrm{i}} \mathrm{t} \operatorname{Sin}(2 \theta)}{4 E_{\mathrm{f}} I_{\mathrm{c}} \mathrm{h}}}
$$

Where,

$E_{i=}$ the modules of elasticity of the infill material, $\mathrm{N} / \mathrm{mm}^{2}$

$E_{\mathrm{f}}$ the modules of elasticity of the frame material, $\mathrm{N} / \mathrm{mm}^{2}$

$I_{c}=$ the moment of inertia of column, $\mathrm{mm}^{4}$

$\mathrm{t}=$ the thickness of infill, $\mathrm{mm}$

$\mathrm{H}=$ the centre line height of frames

$\mathrm{h}=$ the height of infill

$\mathrm{L}=$ the centre line width of frames

$1=$ the width of infill

$\mathrm{D}=$ the diagonal length of infill panel

$\theta=$ the slope of infill diagonal to the horizontal.

Infills frame with Opening: Area of opening, $\mathrm{A}_{\text {op }}$ is normalized with respect to area of infill panel, $\mathrm{A}_{\text {infill }}$ and the ratio is termed as opening percentage $(\%)$. 
Opening percentage $(\%)=\frac{\text { Area of openning }(\text { Aop })}{\text { Area of infill(Ainfill })}$

IV. ANALYSIS EXAMPLE

STRUCTURAL DETAIL

\begin{tabular}{|c|c|}
\hline Type of structure & COLLEGE BUILDING $(\mathrm{G}+5)$ \\
\hline ZONE & III \\
\hline $\begin{array}{l}\text { FOUNDATION LEVEL TO } \\
\text { GROUND LEVEL }\end{array}$ & $1 \mathrm{M}$ \\
\hline FLOOR TO FLOOR HEIGHT & $4 \mathrm{M}$ \\
\hline EXTERNAL WALL & $230 \mathrm{MM}$ \\
\hline INTERNAL WALL & $230 \mathrm{MM}$ \\
\hline LIVE LOAD & $5 \mathrm{KN} / \mathrm{M}^{2}$ \\
\hline MATERIAL & M20 AND Fe415 \\
\hline SEISMIC ANALYSIS & $\begin{array}{l}\text { EQUIVALENT STATIC METHOD (IS } 1893 \\
\text { (Part I) - 2002) } \\
\end{array}$ \\
\hline SIZE OF COLUMN & $\begin{array}{l}\mathrm{C} 1=300 \times 700 \\
\mathrm{C} 2=400 \times 750\end{array}$ \\
\hline SIZE OF BEAM & $\begin{array}{l}\mathrm{B} 1=300 \times 500 \\
\mathrm{~B} 2=300 \times 400\end{array}$ \\
\hline DEPTH OF SLAB & $140 \mathrm{MM}$ \\
\hline DESIGN PHILOSOPHY & LIMIT STATE METHOD CONFORMING (IS 456-2000) \\
\hline DUCTILE DET AILING CODE & IS 13920-1993 \\
\hline
\end{tabular}

Symmetrical View of Building

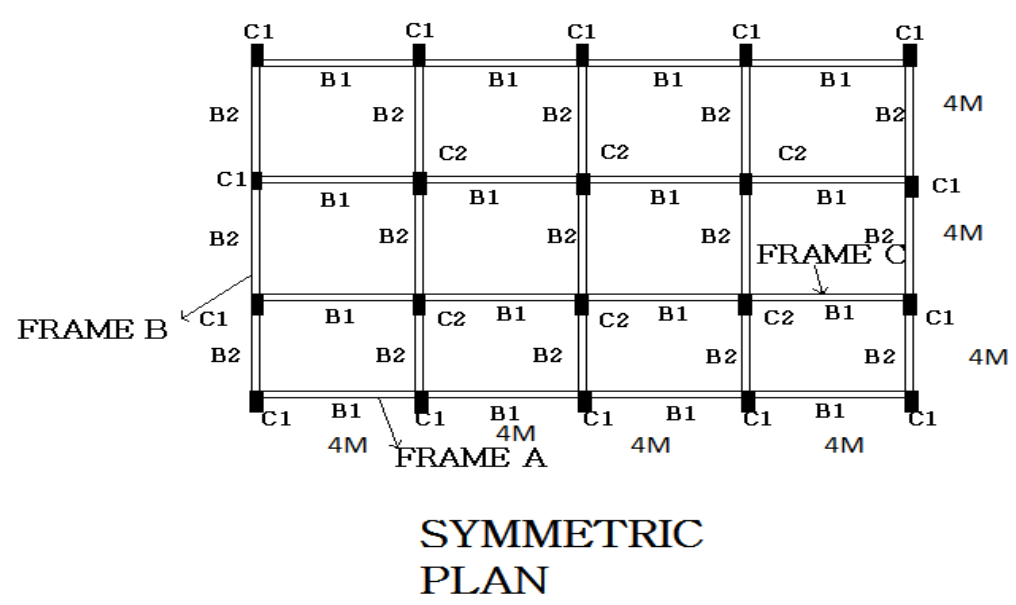

The above mentioned frame has been designed by using STAAD-Pro software. For getting results some column has been selected for getting results and they are as column no.1,2 The results shown in the form of

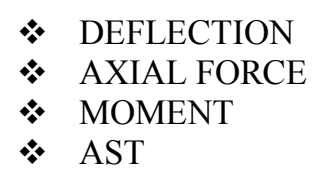

V. Analytical Models Considered

1) Model I. Open Ground Storey of Strut Frame With 15\% Centre Opening (RC Frame with Masonry Infill S.M.R.F. Frame)

2) Model II.Open Ground Storey of Strut Frame With 15\% Corner Opening (RC Frame with Masonry Infill S.M.R.F. Frame)

3) Model III. Open Ground Storey of Strut Frame With 20\% Centre Opening (RC Frame with Masonry Infill S.M.R.F. Frame) 
4) Model IV. Open Ground Storey of Strut Frame With 20\% Corner Opening (RC Frame with Masonry Infill S.M.R.F. Frame)

5) Model III. Open Ground Storey of Strut Frame With 25\% Centre Opening (RC Frame with Masonry Infill S.M.R.F. Frame)

6) Model IV. Open Ground Storey of Strut Frame With 25\% Corner Opening (RC Frame with Masonry Infill S.M.R.F. Frame)

a) Concrete:

\section{Materials:}

Concrete with following properties is considered for study.

- Characteristic compressive strength (fck) $=20 \mathrm{MPa}$

- $\quad$ Poisson's Ratio $=0.3$

- Density $=25 \mathrm{kN} / \mathrm{m}^{3}$

- Modulus of Elasticity (E) $=5000 \mathrm{x} \sqrt{ } \mathrm{fck}=22360.67 \mathrm{MPa}$

b) Steel :

Steel with following properties is considered for study.

- $\quad$ Yield Stress (fy) $=415 \mathrm{MPa}$

- Modulus of Elasticity $(\mathrm{E})=2 \times 10^{5} \mathrm{MPa}$

c) Masonry infill

- Clay burnt brick, Class A, confined unreinforced masonry

- Compressive strength of Brick, $f m=10 \mathrm{MPa}$

- Modulus of Elasticity of masonry (Ei) $=550 \mathrm{x} \mathrm{fm}=5500 \mathrm{MPa}$

- Poisson's Ratio $=0.15$

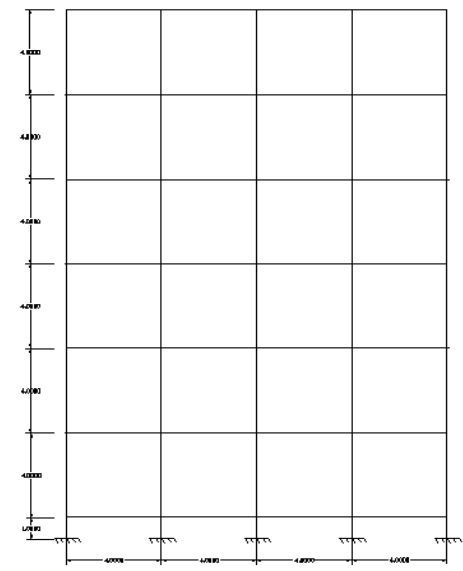

Fig6.1; MODEL I: BARE FRAME

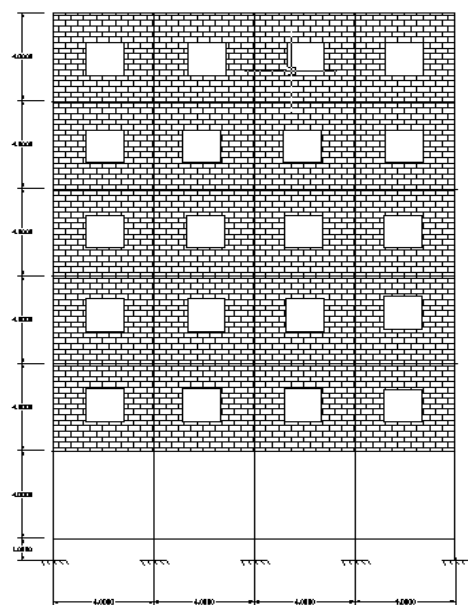

Fig6.3; MODEL III:INFILLED FRAME WITH CENTRE OPENING

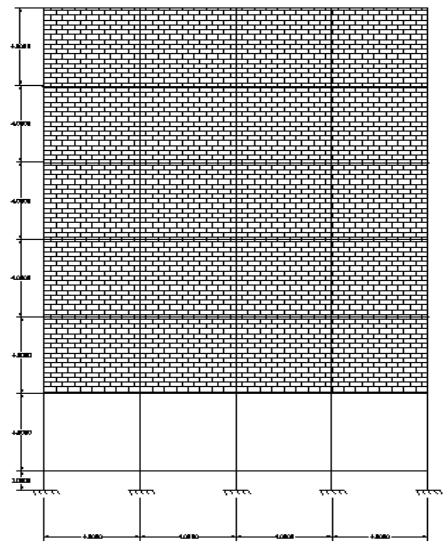

Fig6.2;MODEL II: WITH FULLY INFILLED FRAME

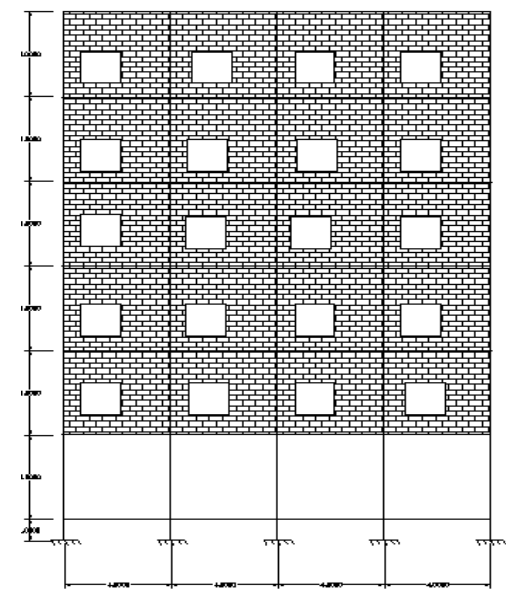

Fig6.4; MODEL IV : INFILLED FRAME WITH CORNER OPENING 


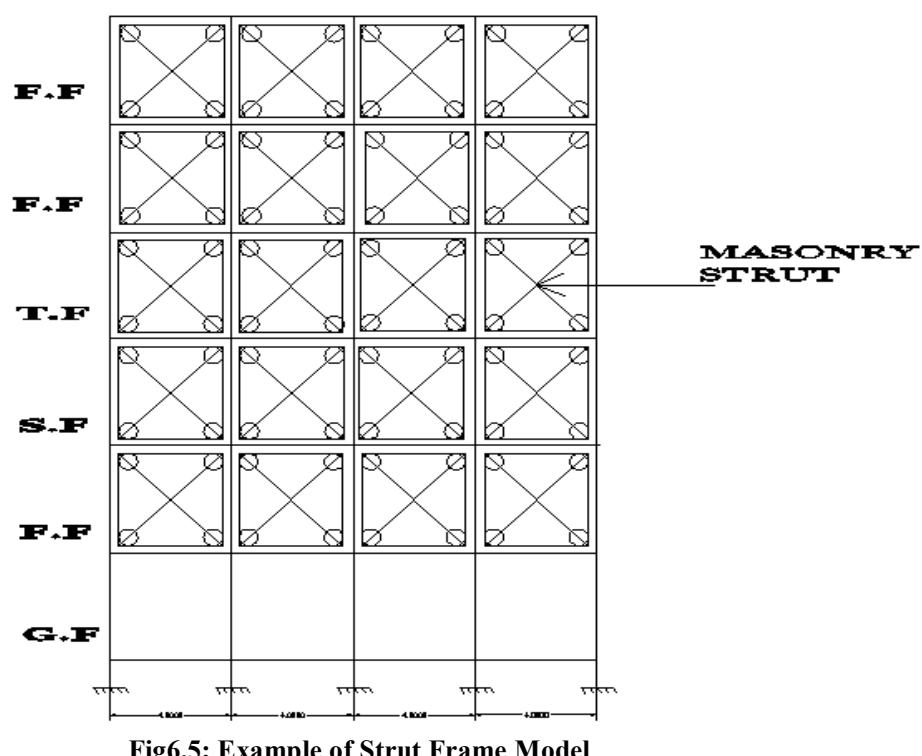

VII. Comparison of Results

Here, Comparison is done in between bare frame and centre and corner opening only. And it is shown with the help of bar graph.

\section{BAR GRAPH}

Fig.7.1 BAR GRAPH FOR DEFLECTION
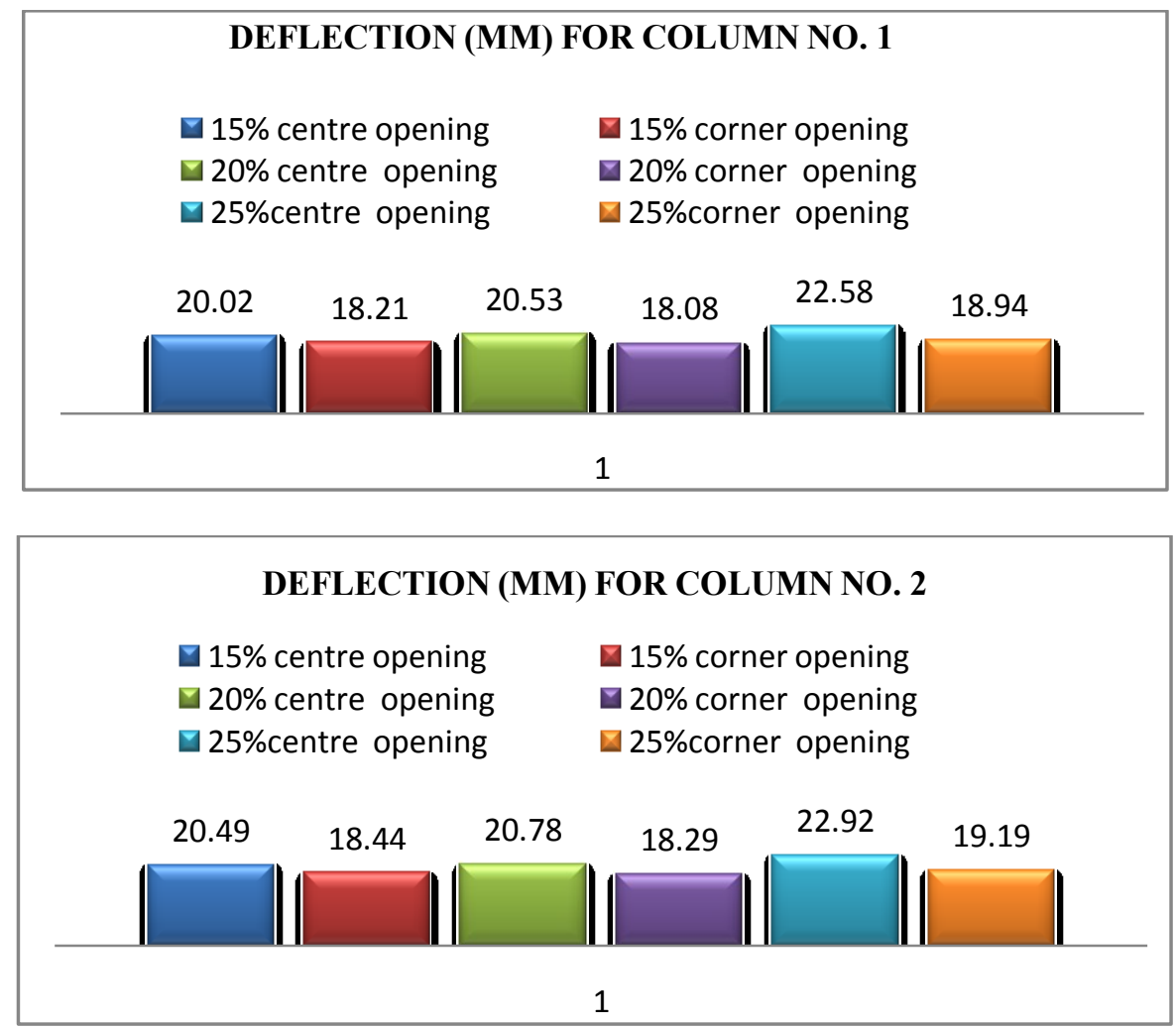


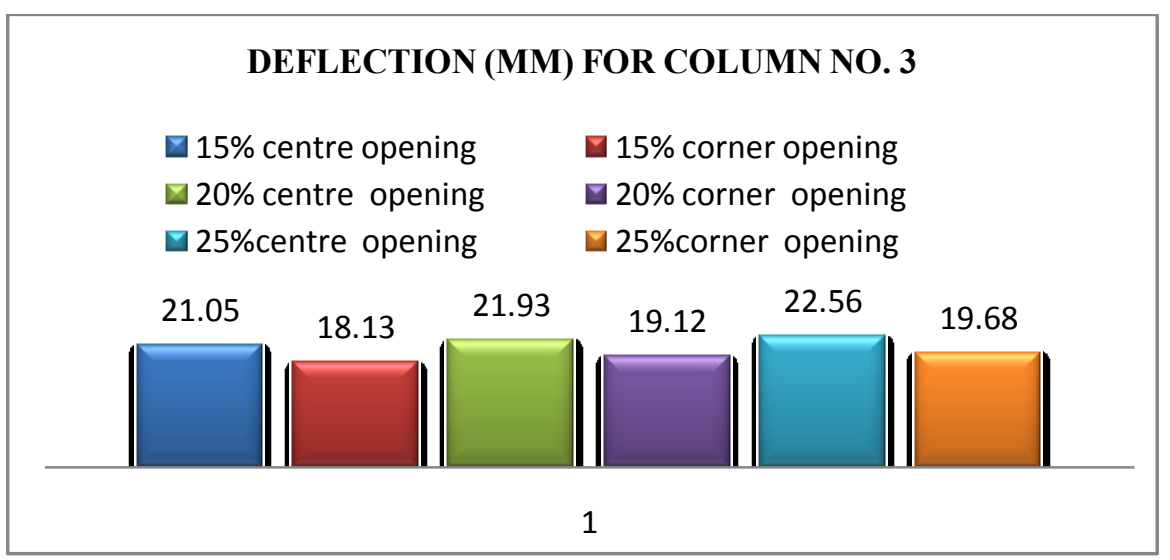

Fig.7.2 BAR GRAPH FOR AXIAL FORCE
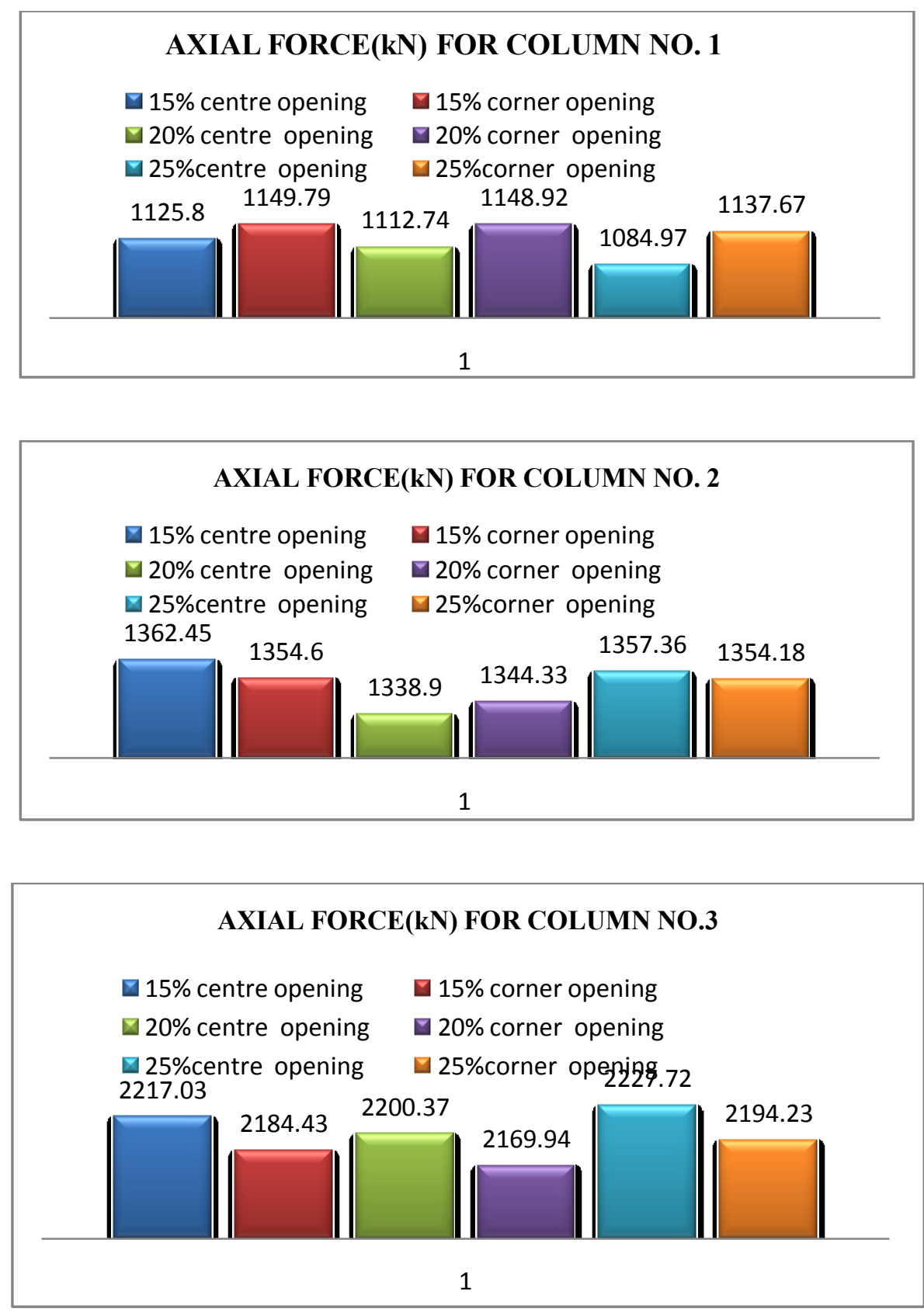
Fig.7.3 BAR GRAPH FOR TOP MOMENT
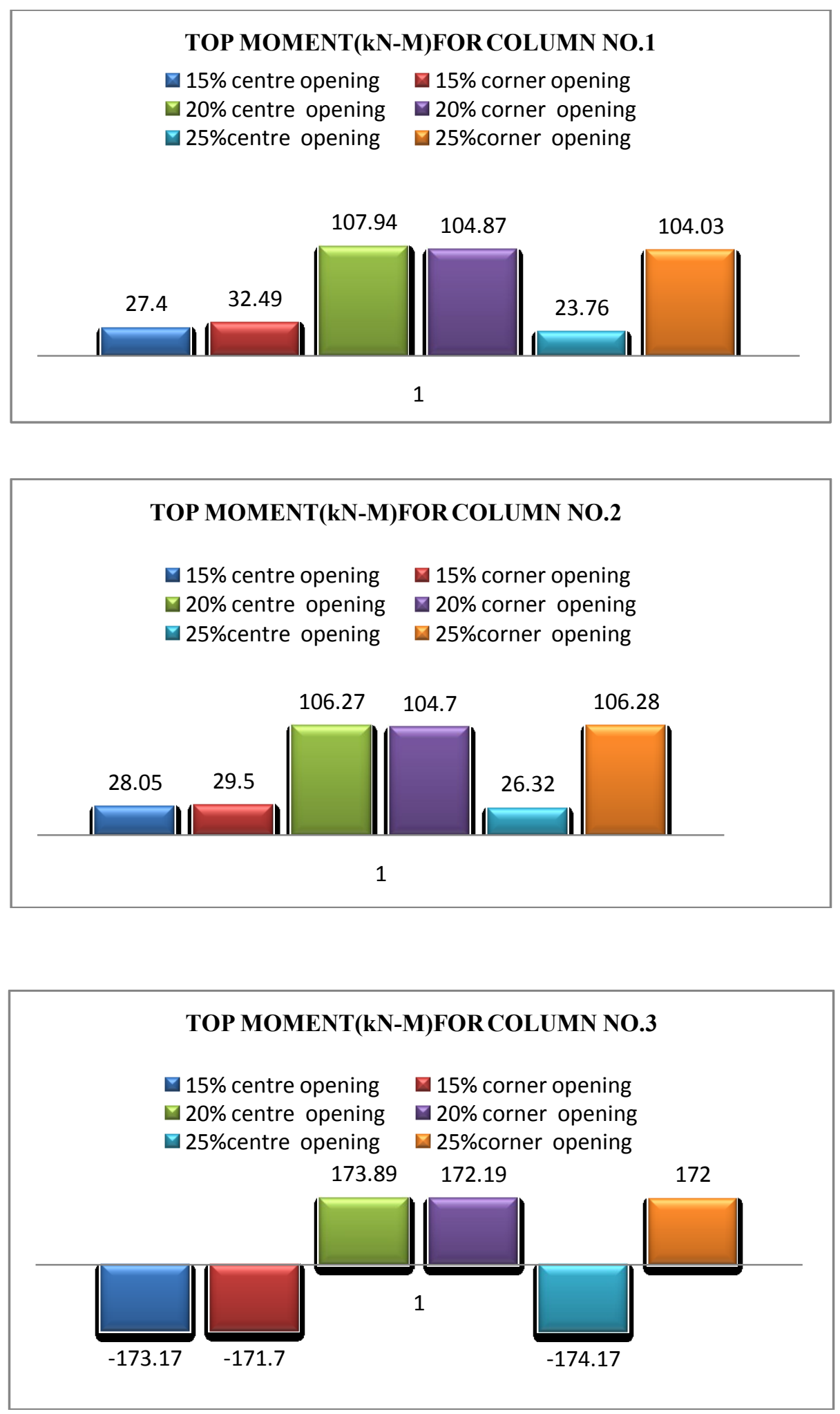
Fig.7.4 BAR GRAPH FOR BOTTOM MOMENT
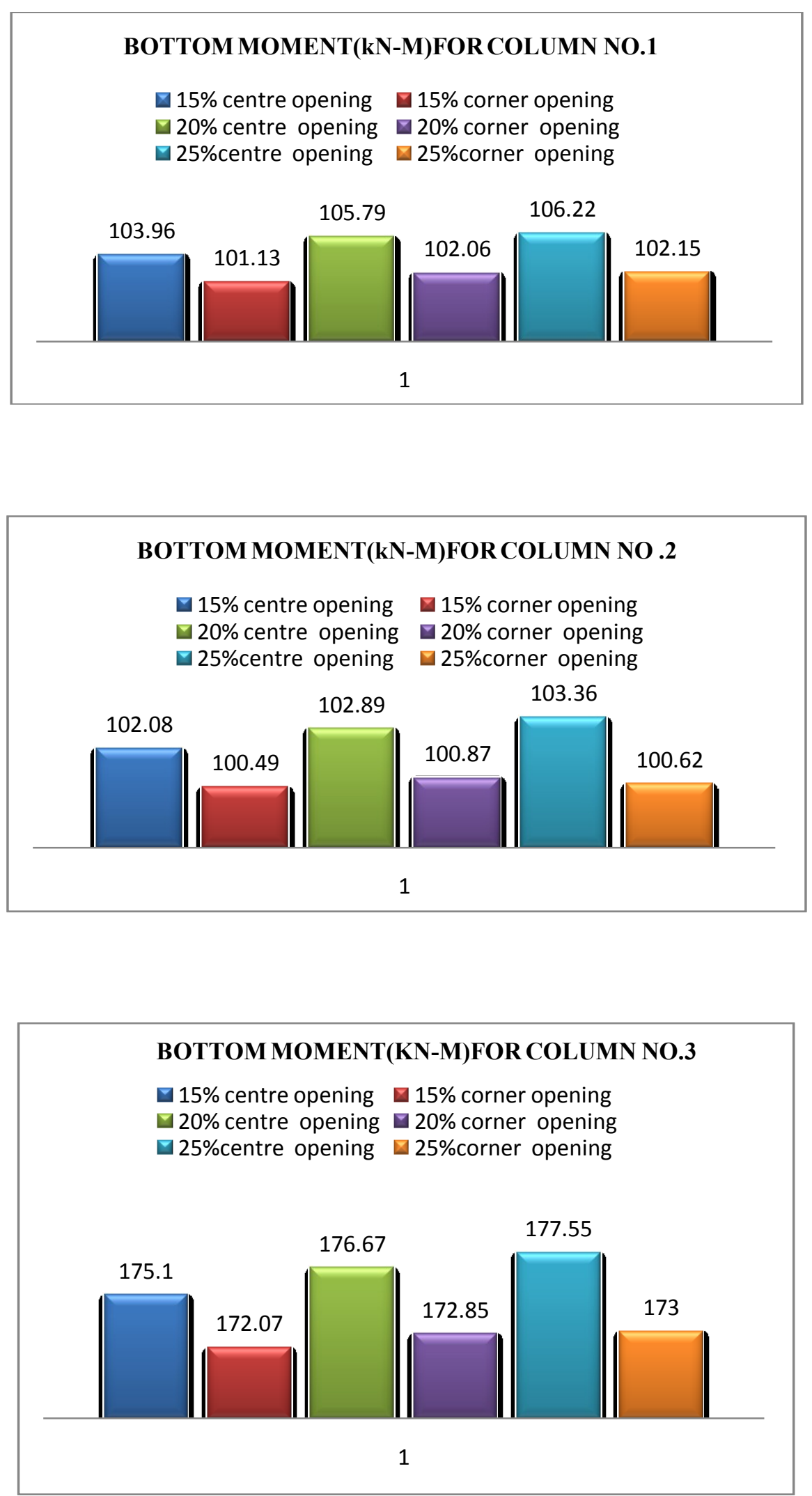
Fig.7.5 BAR GRAPH FOR AREA OF STEEL
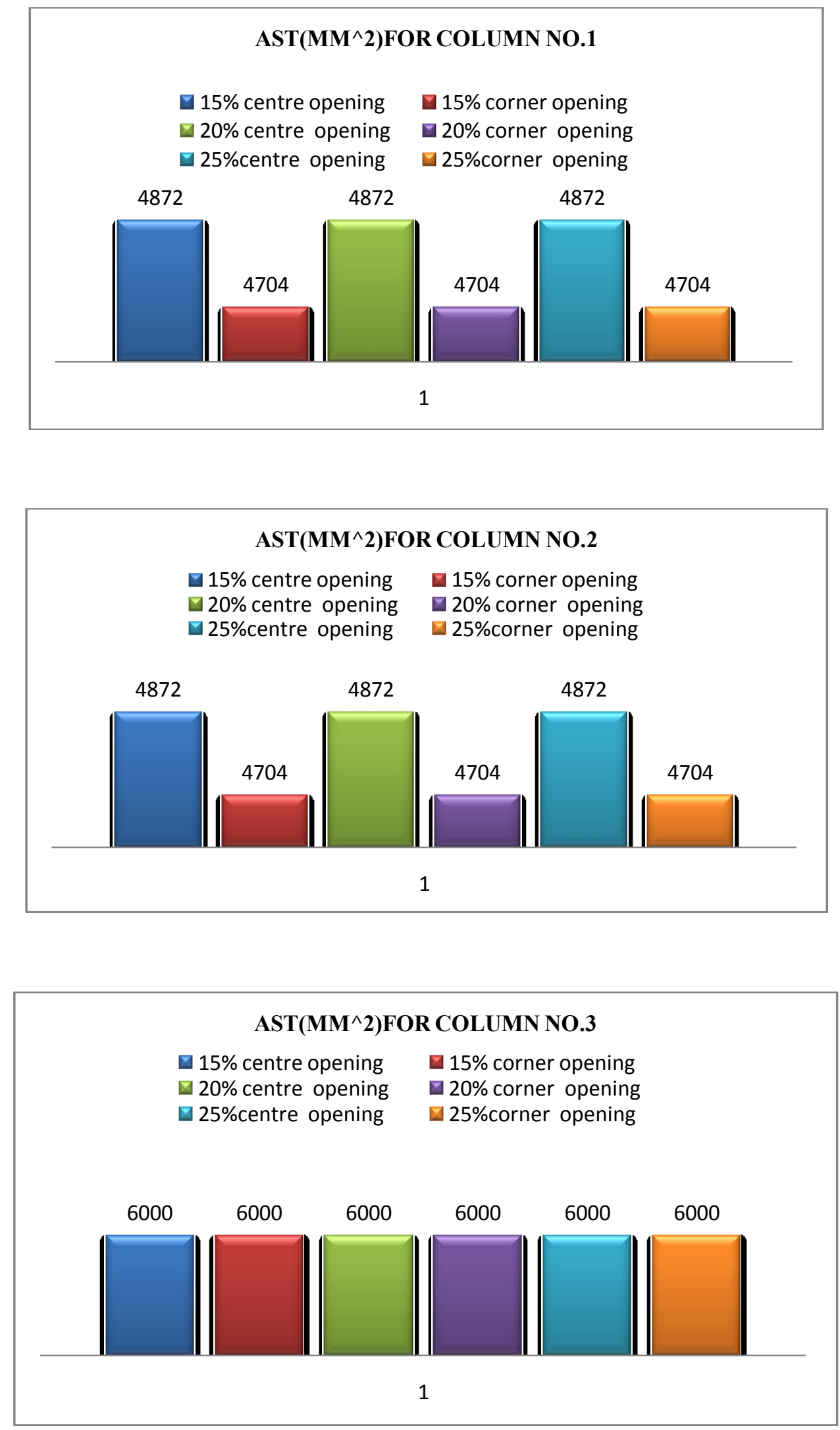


\section{Conclusion}

1. Infill Panels Increase Stiffness of The Structure.

2. The Maximum In Deflection In Bare Frame For $(\mathrm{G}+5)$ Is $105.05 \mathrm{~mm}$ And In Strut Frame It Is Minimum Which $17.84 \mathrm{~mm}$ At Highest Storey Level Is. If The Effect Of Infill Wall Is Considered Then The Deflection Has Reduced Drastically.

3. The Maximum Deflection In Infilled Frame For $(\mathrm{G}+5)$ With $15 \%$ Centre Opening Is $21.05 \mathrm{~mm}$ Which Is $21.93 \mathrm{~mm}$ In $20 \%$ Centre Opening And 23.59mm In $25 \%$ Centre Opening. Hence, As The Opening Percentage Increases It Leads To Increase In Deflection Respectively.

4. The Maximum Axial Force In Infilled Frame For $(\mathrm{G}+5)$ With $15 \%$ Centre Opening Is $2217.03 \mathrm{kN}$ Which Is $2200.37 \mathrm{kN}$ In 20\% Centre Opening And $2227.72 \mathrm{kN}$ In 25\% Centre Opening. Hence, As The Opening Percentage Increases It Leads To Increase In Axial Force Respectively.

5. The Maximum Deflection In Infilled Frame For $(\mathrm{G}+5)$ With $15 \%$ Centre Opening Is $21.05 \mathrm{~mm}$ And 18.44mm In 15\% Corner Opening. Thus The Deflection In Centre Opening Is More Than The Corner Opening.

6. From This Present Result It Shows That, Deflection Is Very Large In Case Of Bare Frame As Compare To That Of Infill Frame With Opening. If The Effect Of Infill Wall Is Considered Then The Deflection Has Reduced Drastically. And Also Deflection Is More At Last Storey Because Earthquake Force Acting On It More Effectively.

\section{References}

[1] J. Dorji* and D.P. Thambiratnam "Modelling and Analysis of Infilled Frame Structures Under Seismic Loads" The Open Construction and Building Technology Journal, 2009.

[2] Luis Decanini, FabrizioMollaioli, Andrea mura, Rodolfo Saragoni "Seismic performance of masonry infilled R.C frame" 13th World Conference on Earthquake Engineering Vancouver, B.C., Canada August 1-6, 2004

[3] Akkar, S.D. and Metin, A. (2007). Assessment of improved nonlinear static procedures in FEMA 440. Journal of Structural Engineering, ASCE, 133(9):1237-1246.

[4] Albanesi, T. Nuti, C. and Vanzi, I. (2000). A simplified procedure to assess the seismic response response of nonlinear structures. Earthquake Spectra, 16(4):715- 734

[5] A. Syrmakezis and P. G. "Influence of infilled walls with openings to the seismic response of plane frames" $9^{\text {th }}$ Canadian Masonry Symposium.

[6] D.K. Bell and B.J.Davidson "Evaluation of Earthquake Risk Buildings with Masonry Infill Panels" NZSEE 2001 Conference P.G. Asteris "Finite Element Micro-Modeling of Infilled Frames" Electronic Journal of Structural Engineering (8) 2008

[7] KasımArmagan KORKMAZ, Fuat DEMIR and Mustafa SIVRI "Earthquake Assessment of R/C Structures with Masonry Infill Walls" International Journal of Science \& Technology Volume 2, No 2, 155-164, 2007

[8] Salah El-Din FahmyTaher and HamdyMohy El-Din Afefy "Role of masonry infill seismic resistance of RC structures" Paper Received 16 April 2007; Revised 4 September 2007; Accepted 28 November 2008.

[9] C V R MURTY AndSudhir K JAIN "Beneficial influence of masonry infill walls on seismic performance of RC frame buildings" 12WCEE 2000, 1790

[10] Kashif Mahmud, Md. Rashadul Islam and Md. Al-Amin "Study the Reinforced Concrete Frame with Brick Masonry Infill due to Lateral Loads" International Journal of Civil \& Environmental Engineering IJCEE-IJENS Vol: 10 No: 04.

[11] FEMA 273 "NEHRP guidelines for the seismic rehabilitation of buildings" federal emergency management agency.

[12] R. V. Dawson and M. A. Ward "Experimental Study of Framed Structure With and Without Infill Walls" Experimental Mechanics

[13] SiamakSattar and Abbie B. Liel "seismic performance of reinforced concrete frame structures with and without masonry infill walls"

[14] T.C. Liaum "An effective structural systems against earthquake infilled frames" vintzeliou e. \& tassios t.p. "seismic behaviour and design of infilled RC frames", International Journal of Earthquake engineering seismology Vol III, n.2,1989,pp. 22-28

[15] Liauw T.C., “An Aproximate Methods Of Analysis for infilled frames with or without opening”. Building Science, vol.7, 1972, pp. 233-238

[16] Maistone R.J. "Supplement Note on the stiffness and Strength of infilled frames" Current paper C.P. 1314, building Research stations, Watford, UK, Feb. 1974.

[17] V.K.R. Kodur "Seismic behavior and design of masonary infilled frames" Civil Engg. Research report CE 94-1

[18] Maistone R.J. ,Supplement Note on the stiffness and Strength of infilled frames' Current paper C.P. 1314, building Research stations, Watford, UK, Feb. 1974.

[19] Amadio, C. and Rajgelj, S. (1991). Shear behavior of brick-mortar joints. Masonry International, 5(1):19-22.

[20] IS: 1893-2002, Criteria for Earthquake Resistant Design of Structures, Part 1, Bureau of Indian Standards, New Delhi, India.

[21] IS: 13920-1993, ductile detailing of reinforced of concrete structure subjected to seismic forces code of practice. 